ISSN 0103-7013

Psicol. Argum., Curitiba, v. 28, n. 62, p. 275-277 jul./set. 2010

Licenciado sob uma Licença Creative Commons

\title{
Planejamento de carreira: Um passo para mais além da Orientação Profissional
}

\author{
Dias, M. S. L., Soares, D. H. P. (2009). Planejamento de carreira: Uma orientação para estudantes uni- \\ versitários. São Paulo: Vetor.
}

\author{
Mariita Bertassoni da Silva
}

Psicóloga formada pela Pontifícia Universidade Católica do Paraná (PUCPR), orientadora profissional, Mestre em Educação pela Universidade Federal do Paraná (UFPR), professora adjunta e supervisora de estágio do curso de Psicologia, coordenadora do Programa de Orientação Profissional da Aliança Educativa da PUCPR, Curitiba, PR - Brasil, e-mail: mariitabertassoni@hotmail.com

O fim de um curso superior representa um "momento singular que demanda muitas informações e reflexões sobre o amanhã” (p. 13). É um momento permeado de angústias, dúvidas e incertezas quanto à própria capacidade ou às oportunidades de inserção num mercado de trabalho competitivo, mutante e desconhecido. Esses receios combinados com a grande quantidade de tarefas acadêmicas a serem realizadas resultam na "falta de tempo para planejar suas vidas após a formatura" (p. 16).

A partir das experiências das autoras com jovens formandos de diferentes graduações, nas aulas da disciplina de Orientação e Planejamento de Carreira oferecida pelo Departamento de Psicologia da UFSC, e coordenada pelo Laboratório de Informação e Orientação Profissional (LIOP), uma como docente e ambas como pesquisadoras, é que surgiu a ideia deste livro, que tem como objetivo maior "possibilitar aos universitários uma reflexão sobre o seu projeto profissional por meio do planejamento de suas carreiras" (p. 18).

Dulce Helena Penna Soares, psicóloga, Mestre em Educação pela UFRGS, Mestre em Psicologia pela Université de Paris-X e Doutora em Psicologia pela Universidade Louis Pasteur Strasbourg, é professora Doutora da UFSC, com ampla experiência em orientação profissional e de planejamento de carreira, autora e coautora de livros e artigos na área, foi sócia-fundadora e presidente da Associação Brasileira de Orientação Profissional (ABOP). Maria Sara de Lima Dias é psicóloga, Mestre em Psicologia da Infância e Adolescência pela UFPR, Doutora em Psicologia pela UFSC e pesquisadora no LIOP, do curso de Psicologia da Universidade Federal de Santa Catarina.

O livro representa uma importante contribuição para profissionais e pesquisadores que se ocupam dessa temática, e principalmente para os formandos. A obra está organizada em 13 partes e oito capítulos, abrangendo uma diversidade de perspectivas sobre a carreira acadêmica, o mundo do trabalho e suas 
características. A linguagem é acessível e os depoimentos dos formandos favorecem a leitura, tornando-a próxima e prazerosa, como se participássemos de um "bate papo" qualificado.

A apresentação, na qual o objetivo da obra é explicitado, é iniciada com um trecho do livro Alice no país das maravilhas (Carroll, 2002), o qual estabelece uma feliz metáfora entre as aventuras de Alice e os anseios do jovem num mundo confuso e sem parâmetros conhecidos.

$\mathrm{Na}$ introdução, Dias e Soares fundamentam suas ideias a partir de Gramsci (2005), Harvey (2005) e Freud (1975), articulando razão, vontade, otimismo/pessimismo, mal estar e as complexidades do contexto do mercado de trabalho na atualidade. Autores como Pochmann (2002), Aued (2002), Castells (2000, 2002) também participam das discussões conceituais que envolvem o subjetivo e o objetivo na construção de uma trajetória profissional.

O capítulo 1, denominado "A escolha da profissão", tece comentários acerca da liberdade (muitas vezes vigiada!) para a escolha, as influências e a responsabilidade diante dela.

O "conhecimento de si" é o tema do segundo capítulo, que envolve reflexões sobre identidade (pessoal e profissional), o projeto de vida e, dentro dele, o profissional, além do projeto familiar.

O capítulo 3 versa sobre "os anos universitários", trazendo as principais características da realidade acadêmica, os mitos e verdades que permeiam esse ambiente, os estágios, os programas trainee e seus significados como preparação para a inserção ocupacional.

A díade trabalho x emprego, empregabilidade e empreendedorismo é central na discussão do capítulo 4, com o título de "O mundo do trabalho". Ele serve de base para a quinta parte do livro, que é a "A inserção no mundo do trabalho", em que as autoras intercalam dados de pesquisa sobre a inserção ocupacional dos jovens com temas concretos de utilização imediata, como implementação de políticas públicas para essa clientela, até o preparo para entrevistas de emprego, elaboração de currículo e networking. Esses dois capítulos citados são complementados com questões relacionadas ao "mercado de trabalho", tais como cultura das organizações, taxas de desemprego, evolução tecnológica, globalização e exigências do mercado de trabalho, que são trabalhados no capítulo 6.

"O planejamento de carreira", título e tema do capítulo 7, trata de vários dos paradoxos ao se pensar uma carreira, conceitua historicamente o termo e apresenta de forma didática e objetiva o conceito de âncoras de carreira segundo Schein (1993).

O capítulo 8, “Técnicas para sala de aula”, traz um pouco da história do surgimento da disciplina de Orientação Profissional e Planejamento de Carreiras, e instiga outras instituições de ensino superior a investir no preparo dos jovens para a necessária transição do papel de alunos para o papel de profissionais, pois o presente muda o passado e altera o futuro, se fornecermos condições e espaço para a reflexão do sujeito.

Nas "Considerações Finais", as autoras ressaltam alguns dos pontos essenciais de sua proposta:

O planejamento de carreira significa, ao mesmo tempo, um grande desafio e uma oportunidade para a Orientação Profissional (OP). Para muitos desses jovens, representa o auxílio necessário numa fase de grande ansiedade, estresse e insegurança quanto ao futuro (p. 256).

Referências e anexos explicativos, esclarecedores e úteis completam o obra.

Alguns lapsos editoriais, como problemas de digitação com repetição de frases ou junção de palavras no texto, não diminuem o brilho do conteúdo e a importância dessa obra, tanto para orientadores profissionais, docentes e pesquisadores, como também para os próprios formandos, que embora não encontrem nela uma "panacéia" para a questão da inserção no mercado de trabalho, encontram sim subsídios para a reflexão e instrumentos que possibilitam a construção mais autônoma e consciente de seu projeto de futuro. Parabéns às autoras pela excelente obra que chega num momento extremamente propício! 


\section{Referências}

Aued, B. W. (Org.). (2002). Educação para o (des)emprego, ou quando estar liberto da necessidade de emprego é um tormento. Petrópolis: Vozes.

Carroll, L. (2002). Alice. Rio de Janeiro: Zahar.

Castells, M. (2000). O poder da identidade. Rio de Janeiro: Paz e Terra.

Castells, M. (2002). A sociedade em rede. Rio de Janeiro: Paz e Terra.

Freud, S. (1975). O futuro de uma ilusão. In S. Freud. Edição standard brasileira das obras psicológicas completas de S. Freud. Rio de Janeiro: Imago.

Harvey, D. (2005). Condição pós-moderna. São Paulo: Loyola.

Pochmann, M. (2002). E-trabalho. São Paulo: Publisher Brasil.

Schein, E. (1993b). Career anchors: Discovering your real values. SanDiego: Pfeiffer \& Company.

Recebido: 30/06/2008

Received: 06/30/2008

Aprovado: 30/10/2009

Approved: 10/30/2009 